\title{
Overview of Multiple Calculating Methods for Land Expropriation Compensation Standard --- A Case of Arable Land in Nanyang, Henan Province, China
}

\author{
Xiaoshan Hu \& Ruiping Ran \\ College of Economics and Management, Sichuan Agricultural University \\ Wenjiang 611130, Sichuan, China \\ E-mail: tiger5356@163.com
}

Received: December 29, 2011

Accepted: January 17, 2012 Published: April 1, 2012

doi:10.5539/ass.v8n4p90

URL: http://dx.doi.org/10.5539/ass.v8n4p90

\begin{abstract}
With accelerating of industrialization and urbanization, the speed of China farmland conversion is astonishing, and land expropriation compensation and interests of land deprived farmers generated thereby also become a focus the society. Although there have been qualitative improvement on both compensation for arable land and security of farmers' social welfare in the last few years, the phenomena of forcible expropriation of land and low compensation for the land by the government in remote areas are still too numerous to mention and the issue of compensation for land deprived farmers is a crucial issue that is concerned with farmers' interests and social security. Therefore, it is necessary to explore a legal and rational land expropriation compensation standard to guarantee interests of land deprived farmers.
\end{abstract}

Keywords: Land expropriation compensation, Arable land, Farmers' interests

\section{Introduction}

Although China has set up a relatively complete arable land protection system, the effect of arable land protection is not optimistic. From 1997 to 2010 , the total arable area in the whole country reduced by 123 million $\mathrm{Mu}$, with an annual reduction of $9.4615 \mathrm{Mu}$. The trend of aggravated reduction of arable land has not got under effective control. An important reason that has caused lose of arable land to a large extent is that the country has not set up a perfect economic compensation system for arable land and resettlement security for deprived farmers after land expropriation exists only in name.

It is generally believed by domestic land expropriation compensation theoretical circle that the country should give out the resettlement grants (sometimes including land compensation) at once to farmers and let them find their own means of livelihood. Irrationality of this sort of compensation is also a focus of controversy by the current theoretical circle which mainly contains irrationality of land expropriation compensation standard, appreciation of land not included in land expropriation compensation standard, no consideration of differences of regional economic development that might lead to differences of land price and irrationality of allocation of land expropriation compensation as well as unequal distribution of land expropriation compensation among all stakeholders, etc. Farmers are the participants and constructors of industrialization and urbanization and they are supposed to become a beneficiary. Thus, it is necessary to take effective measures to protect interests of land deprived farmers (He Zhian, 2007). The result of an analysis of survey on interest security of land deprived farmers in Zhejiang indicates that interests of land deprived farmers have not obtained due compensation and security and there is a great gap and disharmony between will and request of land deprived farmers. Thus, the government has proposed and promulgated land expropriation compensation regulations and put forward policies to standardize the distribution behavior (Liu Weidong, 2006).

It is generally acknowledged by the existing research achievements that land expropriation of farmers in a necessary phenomenon in social and economic development and progress of urbanization. Yet, at present, land expropriation compensation does not conform with the actual situation of the country and does not have perfect security measures. Especially when arable land is expropriated, as a result of remoteness of the arable land and insufficient self legal protection of farmers, the compensation that is originally inadequate is reduced again and 
again and the living of farmers who are deprived of land even become more impoverished. Thus, it is imperative to work out new compensation mechanism and security measure.

\section{Status quo of land expropriation compensation in Nanyang and existing problems}

\subsection{Status quo of land expropriation compensation in Nanyang}

Nanyang is the city in Henan Province that has the largest arable land area, in which per capita arable land area is $0.09 \mathrm{hm}^{2}$ and those who are involved in agriculture account for a rate as much as $60.2 \%$. The standard of land compensation land resettlement grants adopts the integrated land section price. Land in this area is generally classified into four levels according to category of land, output value, per capita arable land, position of land, agricultural land level, land supply and demand relation, economic development level and minimum standard of living for urban residents and land section price is worked out for each level of land. It is stipulated in arable land expropriation compensation and resettlement grants that, land expropriation compensation accounts for $40 \%$ and resettlement grants account for $60 \%$.

\subsubsection{Land resettlement grants}

Arable land compensation is paid with six to ten times of the average output value of the arable land three years prior to its expropriation and compensation for expropriation of other land is calculated by half of that for arable land.

Resettlement grants are compensation for land use right and source of farmers' living. Thus, this compensation should belong to those who own the land by contract, namely, farmers. And if the farmers agree that the resettlement grants are allocated by the collective, then this compensation should be used by the collective. Each farmer resettled should get a compensation worth of four to six times of the average output value in the first three years after the expropriation and the highest limit should not exceed 15 times of the average output value.

The highest land resettlement compensation should not exceed 30 times of the average output value in the first threes after the expropriation. Henan Province promulgated "Henan Integrated Land Section Price Standard for Land Expropriation" that came into effect on November 1, 2009, and this compensation standard increased by approximately $20 \%$ more than the original average value.

\subsubsection{Compensation for young crops and ground attachments and compensation for accessory and constructions}

Compensation for young crops and ground attachments is aimed at owners of land property, so this compensation should belong to the owners of property. The standard of this compensation can be adjusted in due course by the municipal government according to the local economic development condition.

\subsubsection{Social security fee}

Henan added social security fee for land expropriation in 2009 and it is managed and used according to "Opinions of Department of labor and Social Security of Henan Province, Department of Land and Resources of Henan Province and Department of Finance of Henan Province about Employment Training and Social Security among Land Deprived Farmers" (Yu Labor Association, (2008) NO. 19). As for different people from different areas, the local government should make suitable adjustment to offer the compensation.

\subsection{Problems existing in land expropriation compensation in Nanyang}

\subsubsection{Irrational land expropriation compensation standard}

Land resettlement compensation is calculated according to "the average output value in the first three years" after the arable land expropriation, which does not coincide with a lot of cases in rural areas. For example, there is even no profit if a certain section of land is stopped being cultivated or is left uncultivated in a certain year or two years or even three years within the three years after the expropriation. In addition, the stipulation that resettlement compensation is several times of the average output value in the first threes after the expropriation of arable land has no evidence at all, since these two have no necessary relevancy.

\subsubsection{Too short time length for land compensation}

It is stipulated in the $20^{\text {th }}$ Article of "Rural Land Contracting Law" in China that, "the contract period of arable land is 30 years. The contract period of grassland is 30 to 50 years. The contract period of forest land is 30 to 70 years and the contract period for particular woods can be extended with approval of the competent department of forestry administration under the State Council". Therefore, the time length for compensation of contract land expropriated should be at least the remaining time of the contract periods of 30 years, 50 years and 70 years subtracted by the length of years that have passed after the land is under contract. 


\subsubsection{Ambiguity of relevant concepts}

How is "the average output value in the first three years after land expropriation" calculated? Whether factors of inflation have been taken into consideration? According to explanation in "Land Administration Law of the People's Republic of China", "resettlement compensation is a sort of compensation given out to settle living of agricultural population who live on the primary production means of land to obtain sources of living". This explanation says nothing more than explain that resettlement compensation is "grants" given out for "living" of land deprived farmers, but has not made clear the content of "living" and the connotation of "grants", which is likely to arouse dispute in real work. It is also specified that the sum of land expropriation compensation and resettlement grants should not exceed 30 times of the average output value in the first three years after land expropriation. This behavior that only stipulates the upper limit but does not stipulate the lower limit becomes a principle for local government in a lot of regions to implement low compensation for land expropriation.

2.2.4 Deficiency of security mechanism in the long run

At present, land is still the most basic living and subsistence security for farmers. At the time when they lose land, they also lose other rights and interests that they share and that are attached to the land. Although a small minority of areas have attempted to set up part of employment security for land deprived farmers, these security also finally exists in name only due to lack of a security mechanism in the long run.

\subsubsection{Single compensation pattern}

According to stipulation by the Ministry of Land and Resources, there are a variety of patterns in resettlement of land deprived farmers, which mainly include but are not limited to monetary resettlement, agricultural production resettlement, re-selection of employment, stock and bonus resettlement and trans-regional settlement, etc. However, in practice, a large majority of regions choose the pattern of monetary compensation at once. This single compensation pattern, unavoidably, gives rise to a variety of phenomena that damage legal interests of farmers, such as, overweight financial burden, compensation standard that is brought down, occupying, intercepting and embezzling compensation and land deprivation and unemployment of farmers, etc.

\section{Calculation of land expropriation compensation standard by multiple means}

\subsection{Revenue Capitalization Method}

The Revenue Capitalization Method is mainly applied to calculate the compensation standard for arable land to be expropriated. The calculation formula is as follows:

$$
p=\frac{a}{r}\left[1-\frac{1}{(1+r)^{\prime}}\right]
$$

Where, $\mathrm{P}$ stands for land price, a stands for annual net land profit, $\mathrm{r}$ stands for land capitalization rate and $\mathrm{n}$ stands for the number of authorized years of land use. Land expropriation makes ownership of land transferred permanently and changes the collective ownership into national ownership. The calculation formula for the price of arable land expropriated is then converted into:

$$
p \quad=\frac{a}{r}
$$

Arable land compensation standard in Nanyang can be generally classified into four levels according to the integrated land section price in Nanyang. Level I includes Lihe Town, Cha'an Town, Xindian Town, Hongniwan Town and Guanzhuang Town under jurisdiction of Wancheng District. Level II includes Jinhua Town, Gaomiao Town, Lihe Town, Huangtaigang Town and Hanjia Town under jurisdiction of Wancheng District and Xiezhuang Town, Angao Town, Shiqiao Town, Luying Town and Qinghua Town under jurisdiction of Wolong District. Level III includes 22 villages of Shangcao, Zhangtang and so on subordinate to Gaomiao Town under jurisdiction of Wancheng District, 13 villages subordinate to Xindian Town, Qinlaozhuang, Dongzhuang, Zhuyuangou, Dongdian, Taishanmiao and so on that are subordinate to Nanzhao County, Guaihe Town, Dushu Town, Guzhuangdian Town and Erlangmiao Town in Fangcheng Town and Wuliqiao Town in Xixia County, etc. Level IV includes towns and villages under jurisdiction of the 11 counties of Nanzhao County, Tongbai County, Neixiang County and Zhenping County, etc. Arable land is the major direction for urban development in the future, especially for site of industrial development.

At present, arable land employs the contracting mode of limited length of years and investment in arable land has certain policy depreciation. Meanwhile, considering risks of cultivating due to natural disasters, the rate of capitalization is supposed to be higher than the one year deposit rate, and, at the same time, lower than the 
average social investment rate. There are various algorithms for capitalization rate. We deducted the price indexes in 2010 at the same period of time by considering growth of agricultural products price indexes from 2005 to 2009. And then by adding the average one year bank time deposit rate and $1 \%$ of risk adjustment (lower in the risk of investment in land) rate in 2010 to get the land revenue capitalization rate. And then we made a weighted mean of respectively $60 \%$ and $40 \%$ with the capitalization rate that was converted from the actual net income. Accordingly, the capitalization rate was confirmed as $4.18 \%$. After measurement, we get the land price of each measurement unit as in the following Table 1.

$<$ Insert Table 1 here $>$

The output value of the total revenue of arable land is mainly confirmed through market survey. The total expense on arable land includes expense on basic supporting facility of arable land and annual frequent expense on agricultural production. The expense of basic supporting facility of agricultural land mainly includes supporting expenses on ditch, channel, field, forest and path, etc. Annual frequent expense of production mainly includes expenses on seed, fertilizer, water, labor force, machinist, pesticide, maintenance of farmland irrigation establishment and relevant interests, etc. The output value of measurement unit is the average output value in 2010 (the same to the following table) and a comparison is made to indicate the root-mean-square error for arable land expropriation in 2010.

\subsection{Market Comparison Approach}

Each town is regarded as a target of evaluation and, according to the actual land expropriation compensation standard that has occurred in the town, we get the result through comparison and correct. The essential formula is as follows:

$$
P=R \times \frac{100}{Q} \times \frac{100}{G} \times T
$$

Where, $\mathrm{P}$ stands for the land expropriation compensation standard in the town; $\mathrm{R}$ stands for the standard for the case of land expropriation; Q stands for correction factor of regional factors; $G$ stands for correction factor of individual factors; $T$ stands for correction index of time. As for the land expropriation cases in the same town, the regional factors are almost the same and there is no need to correct these factors; and there is also no need to correct the individual factors since the same policy is applied in the specific land expropriation process. Establishment of land expropriation standard in all towns in Xiangfan City is to correct the time. Here, we employ the changing rate of land price index for analysis and calculation and we correct the transaction price as the price of the day when the evaluation is made. The formula is as follows:

We correct the price as: the actual transaction price of the day of evaluation $=$ actual transaction price $\times$ (the price index of the day of evaluation / the price index of the day of transaction). The calculation result is shown as in Table 2.

$<$ Insert Table 2 here $>$

\subsection{Hypothetical Development Method}

According to the principle of hypothetical development method, land expropriation compensation can be expressed as: land expropriation compensation standard $=$ land price - land development cost - interests - profits - tax - appreciation of transfer of land ownership - appreciation of land use change

In the above formula, land price represents the land price of a normal market or the transferring price of the government. Measurement in this paper mainly adopts the approximate representation of benchmark land price for urban and township industrial land. Land development cost is the cost used to develop uncultivated land into cultivated land. The government cuts down on the costs in order to attract investment and usually ascertains profits, the appreciation of transfer of land ownership and appreciation of change of land use as zero. Thus, the above formula can come down to: land expropriation compensation standard $=$ land price - land development cost - interests - tax fee.

According to data about benchmark land price in Nanyang, the measurement result is shown in Table 3.

$<$ Insert Table 3 here $>$

\subsection{Net Present Value}

According to the existing land expropriation policy, the new land expropriation compensation standard should not be lower than the current land expropriation compensation standard and should not reduce the living standard of land deprived farmers as a result of land expropriation, but should, instead, satisfy the minimum living 
demand of farmers.

According to the standard of keeping the living level of farmers unchanged, we measure the new land expropriation compensation standard in Nanyang, which is, in essence, to measure the net present value of income in the future based on the current annual net income of farmers and the growth trend.

According to relevant social security policy of the nation, the regulations in the agricultural land contract system with remuneration linked to output and the actual situation of Nanyang, we define the time scope of profits of arable land in the future as 20 years. Then, the discounting of the income of farmers that comes from land expropriated in Nanyang can be calculated by the following formula:

$$
P=\frac{a \times b}{g \times(r-s)} \times\left[1-\left(\frac{1+s}{1+r}\right)^{n}\right]
$$

Where, $\mathrm{P}$ stands for the net present value of income of land deprived farmers that is obtained from an unit area in the future; a stands for the annual net income of farmers at present; $b$ stands for the ratio of net income of arable land to the annual net income of farmers; $s$ stands for the growth speed of annual net income of farmers in the future; $r$ stands for the discount rate of capital; $g$ stands for per capita arable land area.

Calculated according to the net present value of the income of land deprived farmers in Nanyang in the forthcoming 20 years, if the growth rate of annual net income of farmers in the future is calculated by the annual average speed of $11.5 \%$ and the discount rate of capital is calculated by the one year loan rate of $6.56 \%$, then the result is shown as in Table 4.

$<$ Insert Table 4 here $>$

\section{Determination of land expropriation compensation standard}

\subsection{The principles to determine land expropriation compensation standard}

4.1.1 The principle of protecting legal interests of land deprived farmers, which is to confirm that the previous living standard of land deprived farmers will not become worse as a result of land expropriation and to reflect demand on long-term livelihood and development in the future.

4.1.2 The principle of the same land price for the same land, which means that the land expropriation standard for different parcels of land in the same land section should be identical and should not differ just because of the purpose of land expropriation and differences of land use.

4.1.3 The principle of coordination and balance, which means that the new standard for land expropriation compensation in the same region should be connected with the former compensation standard and land expropriation standard in adjacent areas should be balanced.

4.1.4 The principle of public hearing. According to requirement of "Land and Resources Hearing Provision", the local government should organize a hearing in pursuant to the law and listen to opinions and suggestions from relevant department, rural collective economic organization, farmers and all other fields in the society.

4.1.5 The principle of suitable increase. At the time when the local government calculates the land expropriation compensation according to the current output value of agricultural crops, it is necessary for the local government to improve the production means in an appropriate way and increase scientific investment to enhance land profits.

\subsection{Comparison and overview of land expropriation compensation standards}

\subsubsection{Comparison of land expropriation compensation standards}

We made a comprehensive comparison between actual land expropriation compensation cases in all measurement units in Nanyang and several calculation methods for compensation.

$<$ Insert Table 5 here $>$

We respectively worked out the line graph of calculation results for the four measurement units in Nanyang, as in Figure 1, Figure 2, Figure 3 and Figure 4.

$<$ Insert Figure 1, Figure 2, Figure 3 and Figure 4 here $>$

4.2.2 Overview of calculation methods

From the above line graphs, it is found that each measurement unit applies different measurement methods and get different results that differ from each other. The results show that the land expropriation compensation 
standard in 2010 is 2.51 times more than that in 2007 that was based on the arable land value of the whole country. Arable land expropriation compensation has been greatly increased in Nanyang in 2010 thanks to addition of social security fee, but this is still lower than the arable land price that is calculated with other measurement methods. Besides, what is got in merely the land price based on the annual output value of different land sections in Nanyang in 2010, but has not included young crops compensation and social security fee. In order to protect interests of farmers, we should measure with several methods according to different features of different regions and then extract the maximum value to give compensation to farmers.

The measurement methods that have been employed in this paper are several calculation methods that are frequently used. Since the authors only refer to the annual output value in 2010, they have not applied calculation of output value multiples in "Land Administration Law". Otherwise, they should have obtained a price that is far larger than the actual compensation. In the process of land expropriation, rational determination of land expropriation compensation standard is of great significance to both land deprived farmers and rural collective economic organizations. The original land expropriation compensation is in the light of the annual output value of major agricultural products in the first three years after land expropriation. Actually, calculation of land expropriation compensation standard should have taken into consideration of such comprehensive factors as the location condition of land, economic development condition and local farmers' living level, especially the price of commodities, including rate of inflation. Furthermore, with soaring of material price and housing price, the reference value of the price of grain and oil and vegetable, etc., that were produced by arable land in 2007 and 2008 was too low. Compensation of the average output value in the first three years after land expropriation was unable to secure the living quality of farmers afterwards, let alone compensating the arable land expropriation at the year said with the average output value in the first three years. Authors in this paper suggests that it is the right way to obtain the benchmark standard of arable land compensation and settlement fee by considering the annual output value of the year said, the output value of the previous year and the annual output value of the land one year after measuring the average annual growth rate of arable land output value each year and by calculating the average output value of the three years.

\section{Conclusion}

So far, land expropriation compensation has not contained fees outside agricultural land or fees of agricultural land to secure the national food safety and ecological safety and how these fees should be calculated deserves further discussion. As a result of differences in the geographical locations of all regions, the natural resource conditions and social and economic development levels, the country should take actions to suit local circumstances and take an overall consideration to gradually set up a system to calculate and verify the scientific and rational land expropriation compensation standard. In the process of land expropriation, the policy issues of single compensation pattern and lack of security mechanism in the long run are still to be resolved.

\section{References}

Cao, Tianbang \& Yun, Jianping. (2007). Research on the Determining Methodology of the Rate of Interest to Land Back in Agricultural Land. Journal of Anhui Agricultural Sciences, 35(3):794-795.

Fang, Xianlei. (2010). Study on cultivated land protection policy of our country. Journal of Anhui University, (4). He, Zhian. (2007). Resolve Difficulty in Land Expropriation Compensation. Jiangsu Legal News, May 8.

Jiang, Guanghui \& Kong, Xiangbin, et al. (2009). Analyzing the Mechanism of Economic Compensation for Farmland Protection. China Land Science, (7).

Liu, Hancheng. (2007). Study on Urbanization Progress and Relationship between Arable Land Protection and Land Deprived Farmers. Theory Monthly, (8).

Tang, Jian, et al. (2006). Study on Arable Land Protection System and Policy. Beijing: China Social Sciences Press.

Wang, Shiju, et al. (2008). Study on Compensation Standard of Land Expropriation Based on Value of Cultivated Land. China Land Science, (11).

Ward, D., S. R. Phinn \& A. T. Murray. (2000). Monitoring Growth in Rapidly Urbanizing Areas Using Remotely Sensed Data. Professional Geographer, 52(3):371-386. http://dx.doi.org/10.1111/0033-0124.00232 
Table 1. Land price of arable land in all measurement units in Nanyang

\begin{tabular}{|c|c|c|c|c|c|}
\hline $\begin{array}{c}\text { Number of } \\
\text { measurement } \\
\text { unit } \\
\end{array}$ & $\begin{array}{c}\text { Output value (ten } \\
\text { thousand } \\
\text { Yuan } / \mathrm{hm}^{2} \text { ) }\end{array}$ & $\begin{array}{c}\text { Planting cost (ten } \\
\text { thousand } \\
\text { Yuan } / \mathrm{hm}^{2} \text { ) }\end{array}$ & $\begin{array}{c}\text { Net profit (ten } \\
\text { thousand } \\
\text { Yuan } / \mathrm{hm}^{2} \text { ) }\end{array}$ & $\begin{array}{c}\text { Capitalization } \\
\text { rate }(\%)\end{array}$ & $\begin{array}{c}\text { Land price (ten } \\
\text { thousand } \\
\text { Yuan } / \mathrm{hm}^{2} \text { ) }\end{array}$ \\
\hline I & 11.37 & 5.42 & 5.95 & 4.18 & 142.34 \\
\hline II & 7.80 & 4.73 & 3.07 & 4.18 & 73.45 \\
\hline III & 6.56 & 2.97 & 3.59 & 4.18 & 85.89 \\
\hline IV & 4.50 & 2.10 & 2.40 & 4.18 & 57.42 \\
\hline
\end{tabular}

Table 2. The corrected result of land expropriation compensation standard for each measurement unit in Nanyang

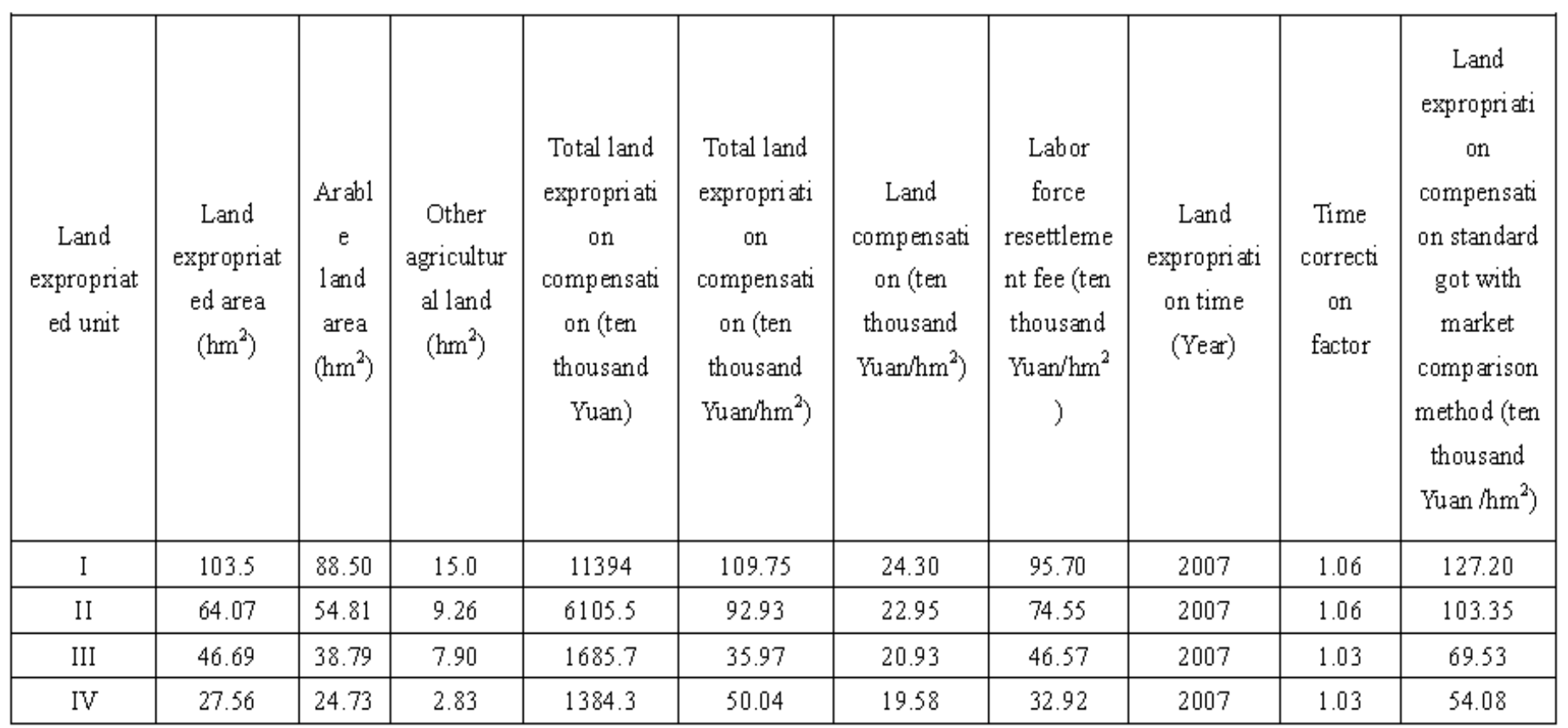

Table 3. Calculation of measuring land expropriation compensation standard with the hypothetical development method in Nanyang

\begin{tabular}{|c|c|c|c|c|}
\hline $\begin{array}{c}\text { Number of } \\
\text { measurement } \\
\text { unit }\end{array}$ & $\begin{array}{c}\text { Land price (ten } \\
\text { thousand } \\
\left.\text { Yuan } / \mathrm{hm}^{2}\right)\end{array}$ & $\begin{array}{c}\text { Land } \\
\text { development cost } \\
\text { (ten thousand } \\
\left.\text { Yuan } / \mathrm{hm}^{2}\right)\end{array}$ & $\begin{array}{c}\text { Interest and tax fee } \\
\text { (ten thousand } \\
\text { Yuan } / \mathrm{hm}^{2} \text { ) }\end{array}$ & $\begin{array}{c}\text { Land expropriation } \\
\text { compensation } \\
\text { standard (ten } \\
\text { thousand Yuan } / \mathrm{hm}^{2} \text { ) }\end{array}$ \\
\hline I & 360 & 120.20 & 93.60 & 146.20 \\
\hline II & 292.50 & 94.83 & 85.98 & 111.69 \\
\hline III & 201.50 & 61.51 & 65.25 & 74.74 \\
\hline IV & 132.70 & 39.34 & 34.46 & 58.9 \\
\hline
\end{tabular}


Table 4. Share of per capita unit arable land area of the income of land deprived farmers in Nanyang in the forthcoming 20 years

\begin{tabular}{|c|c|c|c|c|}
\hline $\begin{array}{c}\text { Number of } \\
\text { measurement } \\
\text { unit }\end{array}$ & $\begin{array}{c}\text { Per capita net } \\
\text { income of farmers } \\
\text { (ten thousand Yuan) }\end{array}$ & $\begin{array}{c}\text { Ratio of net arable land } \\
\text { income to the annual } \\
\text { net income of farmers } \\
(\%)\end{array}$ & $\begin{array}{c}\text { Per capita arable } \\
\text { land area } \\
\left(\mathrm{hm}^{2} / \text { person) }\right.\end{array}$ & $\begin{array}{c}\text { Share of unit arable } \\
\text { land area (ten } \\
\left.\text { thousand Yuan } / \mathrm{hm}^{2}\right)\end{array}$ \\
\hline I & 0.69 & 39 & 0.078 & 103.03 \\
\hline II & 0.57 & 52 & 0.124 & 71.38 \\
\hline III & 0.41 & 39 & 0.097 & 49.23 \\
\hline IV & 0.39 & 34 & 0.066 & 59.99 \\
\hline
\end{tabular}

Table 5. Land expropriation compensation criterion initial determination of land expropriation compensation standard

\begin{tabular}{|c|c|c|c|c|c|c|}
\hline $\begin{array}{c}\text { Number of } \\
\text { measurement } \\
\text { unit }\end{array}$ & $\begin{array}{c}\text { Initial result } \\
\text { standard } \\
\text { (ten } \\
\text { thousand } \\
\text { Yuan } / \mathrm{hm}^{2} \text { ) }\end{array}$ & $\begin{array}{c}\text { Revenue } \\
\text { capitalization } \\
\text { ten thousand } \\
\text { Yuan } / \mathrm{hm}^{2} \text { ) }\end{array}$ & $\begin{array}{c}\text { Market } \\
\text { comparison } \\
\text { approach (ten } \\
\text { thousand } \\
\text { Yuan } / \mathrm{hm}^{2} \text { ) }\end{array}$ & $\begin{array}{c}\text { Hypothetical } \\
\text { development } \\
\text { method (ten } \\
\text { thousand } \\
\text { Yuan } / \mathrm{hm}^{2} \text { ) }\end{array}$ & $\begin{array}{c}\text { Net present } \\
\text { value (ten } \\
\text { thousand } \\
\text { Yuan } / \mathrm{hm}^{2} \text { ) }\end{array}$ & $\begin{array}{c}\text { Average } \\
\text { value of the } \\
\text { five } \\
\text { calculation } \\
\text { methods (ten } \\
\text { thousand } \\
\text { Yuan } / \mathrm{hm}^{2} \text { ) }\end{array}$ \\
\hline I & 108.50 & 142.34 & 127.20 & 146.20 & 103.03 & 125.45 \\
\hline II & 81.80 & 73.45 & 103.35 & 111.69 & 71.38 & 88.33 \\
\hline III & 55.60 & 85.89 & 69.53 & 74.74 & 49.23 & 66.99 \\
\hline IV & 43.50 & 57.42 & 54.08 & 58.90 & 59.99 & 54.78 \\
\hline
\end{tabular}

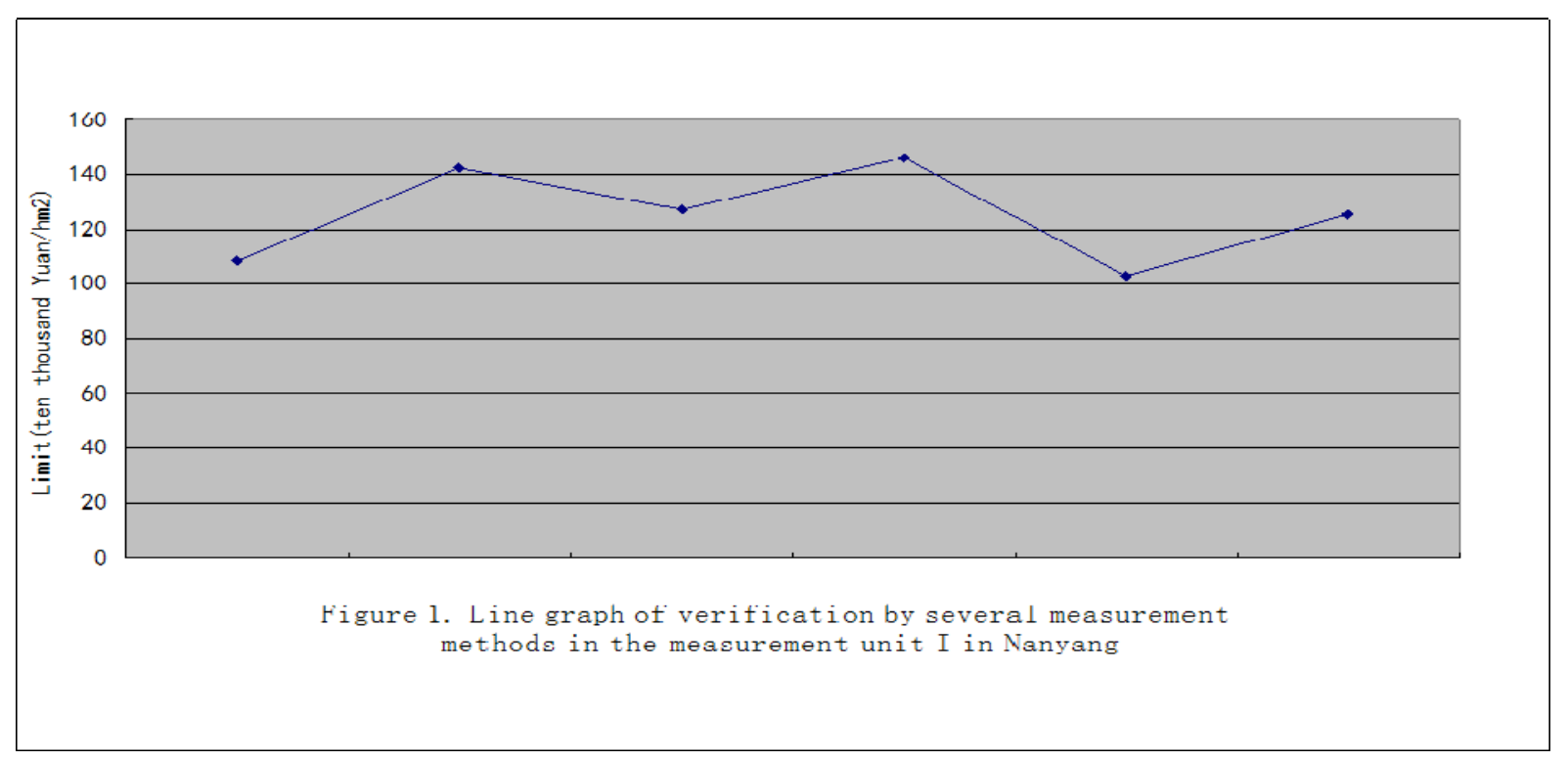



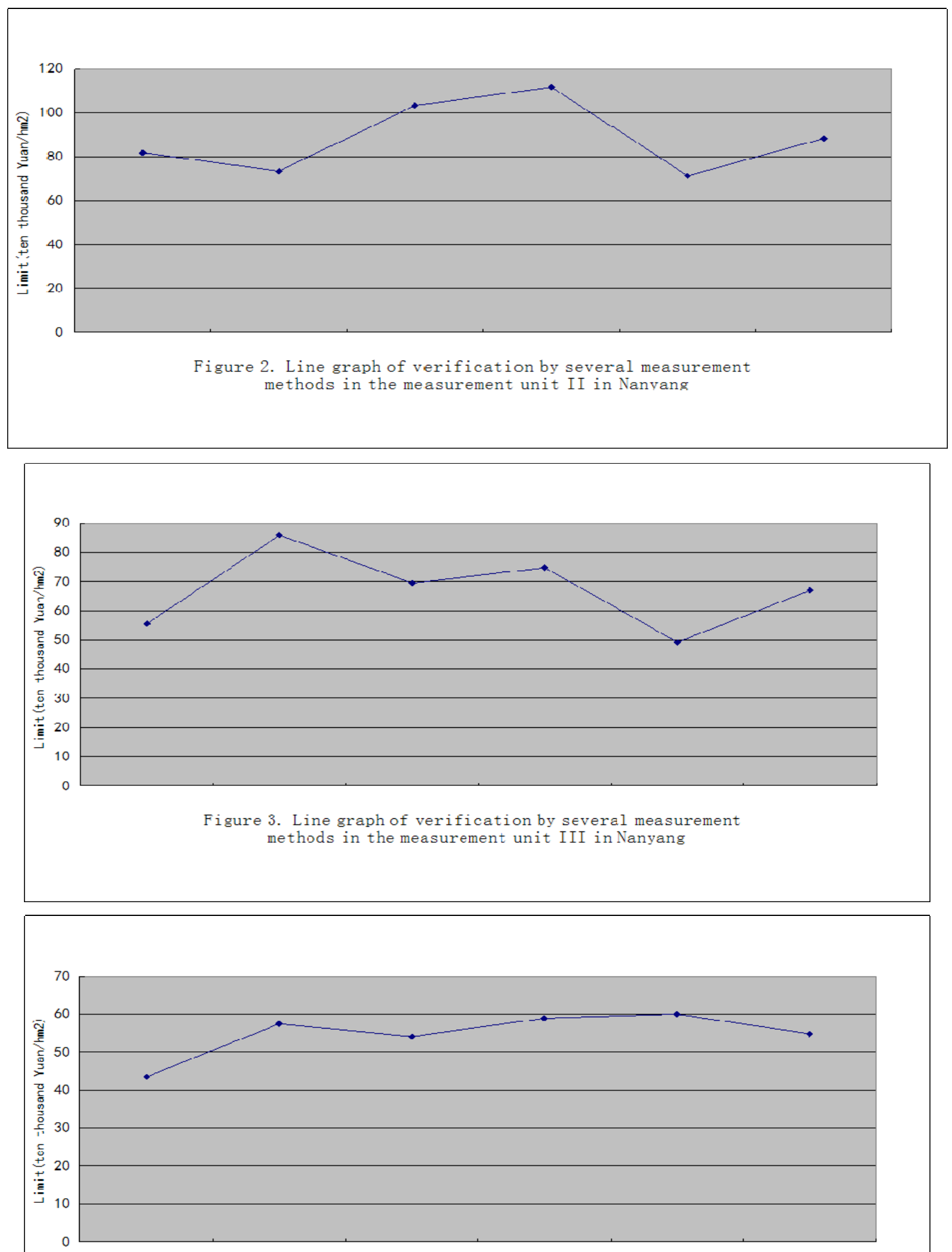

Figure 4. Line graph. of verification by several measurement methods in the measuremer.t unit IV in Nanyang 